\title{
THE ROLE OF SCHOOL PRINCIPAL LEADERSHIP ON QUR'ANIC GENERATION DEVELOPMENT PROGRAM (QGDP) IN ISLAMIC PRIMARY SCHOOL ATHIRAH 1 KAJAOLALIDO MAKASSAR
}

\author{
Harisman \\ Post-Graduate Program \\ Universitas Islam Negeri Alauddin Makassar \\ Jln. H.M. Yasin Limpo No. 36 Samata Gowa \\ Email: ariesenglish88@mail.com
}

\begin{abstract}
The main problem of this research is how the Principal's role in the implementation of the Qur'anic Generation Development Program (Tahsin, Tahfidz, and Tadabbur) in Athirah I Islamic Elementary School Makassar. This research uses qualitative research. The data sources of this research are the Principal, Coordinator of the Koran, and students' participation. Furthermore, the data collection methods used are, observation, and reference tracking. Then, data processing and analysis techniques are carried out through three stages, namely: data reduction, data presentation, and concluding. The results of this study indicate that there are seven steps in the implementation of tahsin, tahfidz, and tadabbur in learning to read the Koran at SD Athirah 1 Makassar, namely: Opening, Apperception, Concept Planting, Concept Understanding, Exercise/Skills, Evaluation, Closing, both in terms of Individual, classical individual, and classical reading.
\end{abstract}

Keywords: Principal, Quranic, Individual Skill, Classical Reading 


\section{Introduction}

The whole human being in the natural world of life is the purpose of his creation as a servant ('aabid). The main task of humans is worshiping Allah Almighty obeying His commands and avoiding all His prohibitions. Worship is rooted in the word 'abada which means to devote oneself to self-servitude. Human relations with Allah. like the relationship of a servant with his god who is always obedient, submissive, and obedient to all the commands of his god. Because of its position as' abid, the obligation of humans on this earth is to worship God with sincerity wholeheartedly.

Humans as well as caliphs and all their activities towards others and their environment will have the value of worship if done based on faith to obtain the pleasure of God. Such as trading, farming, fishermen, employees, studying, etc., in the framework of managing and prospering the earth when done with the intention of worship. Therefore, Allah has entrusted man to take care, manage and prosper the earth, so it is said to be caliph fi al-ardl.

The word caliph initially means that it replaces, or comes after who came before. Based on this meaning, it can be understood that the caliph intends to replace God in upholding His will and applying His decrees, but not because Allah is incapable of making man's position as God, but because Allah intends to test man and give him respect. Some 
understand the caliph in the sense of replacing other creatures in inhabiting and caring for this earth. ${ }^{1}$

The Caliphate requires humans to lead and be led in carrying out their duties according to the instructions of Allah who gave the task and authority. And if the decisions taken by humans are not following His will, then the human being violates the leader also plays a critical role in helping the group of organizations, or society to achieve their goals. However, the ability and skills in direction are important factors for manager effectiveness. If the organization can identify qualities related to the ability to identify effective leadership behaviors and techniques.

Leadership is the strength or quality of a leader in directing what he leads to achieving goals. Like management, leadership or leadership has been defined by experts including Stoner arguing that managerial leadership can be defined as a process of directing the activities of a group of members who also are related to their duties.

Leadership is the ability a person has to influence others to work towards their goals and objectives. Management includes leadership but also includes other functions such as planning, organizing, monitoring, and evaluation. Leadership in the world of education deals with the problem of principals in increasing opportunities to hold meetings effectively with teachers in conducive situations. In this case, the principal's behavior must be able to encourage

${ }^{1}$ M. Quraish Shihab, Tafsir al-Mishbah: Pesan, Kesandan Keserasian al-Qur'an, (Cet. II; Jakarta: LenteraHati, 2004), p. 142. 
the performance of teachers by showing a sense of friendliness, close and full consideration of the teachers, both as individuals and as groups. ${ }^{2}$

Teaching and learning activities, one of which is highlighted is the aspect of program implementation. Whether or not the success of a learning process depends on the accuracy of the program used. Likewise, al-Qur'an learning also requires the right program. Because it is the program that determines the content and how to study the Qur'an well. Thus the program is a very important tool to achieve the goals that have been determined and planned. In addition, the accuracy of choosing a program in its implementation must also be considered as well as the use of the program tahsin, tahfidz, and tadabbur in learning the Koran.

\section{Basic Concepts of Leadership}

Leadership is a word that contains multiple meanings, namely the leader and the leader. Leadership can be accomplished if the leaders and led elements collaborate well. In Arabic literature, leadership is expressed in various words, namely: ${ }^{3}$

${ }^{2}$ Nunuk Suryani "Peran Kepemimpinan Kepala Sekolah dalam Pemamfaatan Media PembelajaranSebagaiUapayaPeningkatanKualitas Proses Pembelajaran”. Jurnal Teknologi Pendidikan, Vol 1 No 2 (2013), p. 228-229

${ }^{3}$ Masniati "Kepemimpinan dalam Islam". Jurnal Al-Qadau, Vol 2 No 1 (2015) p. 58. 


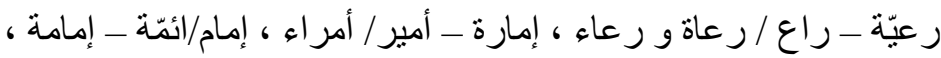

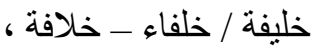

These words in addition to having the same general meaning, revolve around the meaning of the leader, which is led and leadership, also have a special meaning in accordance with the function of its use in the verses of the Koran and hadith. The words will be described in detail based on vocabulary, phrases, and sentences, as follows: term - رعيّة

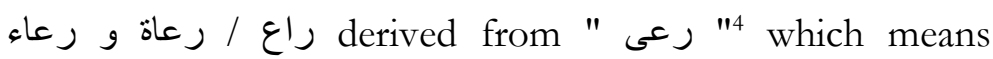
wandering, leading regulating, guarding, maintaining and considering, in-kind al-ism al-fa'ilil راع/ رعاة و رعاع means the

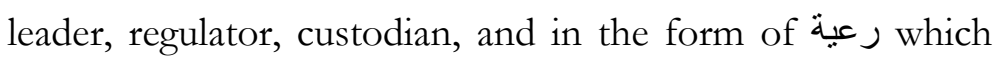
means being led or the people. The word رعيّة is also a form of al-masdar al-sina'iiemasdar which is formed by adding alharf al-ya 'al-nisbah and al-ta' al-ta'nis in the same meaning as al-masdar رعيام weans leadership.

The word أمراء / أمير - إمارة comes from the word "أمئير means to command, control and influence, is a form of al-ism almusyabbahah bi ism al-fa'il from the root of the word amara which means government, authority or amir. The word security implies leadership. In the Koran, the word amir is never found, only the sentence "أولسالأمر" which means the leader of the affairs or the owner of the affairs, namely the government, as the Word of Allah in QS al-Nisa / 4: 59

${ }^{4}$ Ahmad Warson Munawwir, Kamus Al-Munawwir Arab-Indonesia (Cet.XIV; Surabaya: PustakaProgressif 1997), p. 511. 
The Role of School Principal Leadership Quranic...

In connection with the verses of the Koran, which means leaders, then leadership, in this case, is the effort or activity of an owner or ruler of all affairs or government, the head of state to always direct the one led by referring to the guidance of Allah Almighty and the Apostle as a condition to get success in leadership.

"أمّ" comes from the word إمامة ـ أئّة / إمام The word which means to go to, intend, deliberate, become a priest, and lead, while the word إمامة is a form of al-Ism al-masdar from the word أمّ contains various meanings, which means road (Surah al-Hijr / 15: 79), (Surah Yasin / 36:12), guidelines and instructions (Surah Hud / 11: 17 and Surah al-Ahqaf / 46:12)

The word خلافة ـ خلفاء / خليفة comes from the word which means to replace, differ, change and improve, in the form of al-ism almasdar, namely خلافة, containing the meaning of replacement, or caliphate. The word خليفة is a word in the form of al-sifah al-musyabbahab bi alism al-fa'il which خليفة contains the meaning of the performer so that the word means a substitute, leader and caliph. The expression of the caliph can be interpreted more as a creature entrusted and given the task by God to manage and utilize all the natural potential in accordance with its guidance, humans are like God's representatives.

In the Koran, the word Khalifah in the form of mufrad is mentioned in two contexts. First, in the context of the discussion about the Prophet Adam. The Word of God Almighty in QS al-baqarah / 2: 30. The context of this verse 
shows that humans are made caliphs on this earth tasked with prospering or building them in accordance with the concepts set by God. The use of the word caliph in the verses of the Koran, both in singular and plural form can be understood that these words are more connoted to leaders who are given the power to manage a region on earth. The meaning of replacement mentioned in the Koran is the replacement of the generation and replacement of leadership. Generation replacement, namely a generation that obeys is replaced by the generation of dissidents against God's command and the replacement of leadership, namely the replacement of the leadership of the people such as the president, the king also on a small scale, such as social, social and political organizations.

\section{Principal}

The principal is one of the education components that have the most role in improving the quality of education. As stated in article 12 paragraph 1 PP 28 of 1990 that: "the principal is responsible for organizing educational activities, school administration, fostering other education personnel, and the utilization and maintenance of facilities and infrastructure." 5

The principal is the most important person in a school. And researches and informal observations are known to be the head of a school and are the key to the development

${ }^{5}$ E. Mulyasa, Menjadi Kepala Sekolah Profesional (Bandung: Remaja Rosda karya, 2007), p. 25 
The Role of School Principal Leadership Quranic...

and improvement of a school. An indicator of school success is if the school is functioning properly, especially if student achievement can be maximized. ${ }^{6}$ The principal is the functional teacher who is given the task to lead an institution where teaching and learning processes are held or the place where interaction occurs between the teacher giving the lesson and the students receiving the lesson. ${ }^{7}$

Principals as policymakers in schools must also function optimally, Kartini Kartono's statement in Idochi Anwar's book states that the leadership function is to guide, guide, guide, provide or build work motivations, drive organizations, establish better communication networks so that will be able to bring his followers to the planned destination. $^{8}$

\section{Definition of Tahsin, Tahfidz and Tadabbur}

Tahsin (fixing), the word 'tahsin' in the language is taken from the verb hassana-yuhassinu-tabsinan, meaning: repair or decorate, make or beautify or make better than before. Tahsin in Islam implies that the demand that in reading the Koran must be true and correct in accordance with the example for the sake of preserving the originality of the practice of recitation in accordance with the sunnah of the

\footnotetext{
${ }^{6}$ Suharsimi Arikunto,Organisasi dan Administrasi Pendidikan Teknologi dan Kejuruan, (Jakarta: CV. Rajawali, 1990), p. 196

${ }^{7}$ Wahjosumidjo, Kepemimpinan Kepala Sekolah Tinjauan Teoritik dan Permasalahannya (Jakarta: Raja GrafindoPersada, 2005), p. 83.

${ }^{8}$ Moch. Idochi Anwar, Administrasi Pendidikan dan Manajemen Biaya Pendidikan (Bandung: Alfabeta, 2004), p. 78
} 
Prophet Muhammad, ${ }^{9}$ Tabsin is a learning program to read the Koran. In Arabic studies, Arabic phonology is known, which is the field of linguistics or linguistics that investigates, studies, analyzes, and discusses the sequence of language sounds produced by human speech devices and their functions. ${ }^{10}$

Tabfidz, is a program to memorize the Koran, as previously explained that the Koran is in Arabic and this research is more on the language of the Koran as Arabic because it cannot be separated between the language of the Koran and Arabic which is one main subject of Shari'a. Tadabbur according to language is to look at the effects of something and think about it, meaning to pay attention to it from beginning to end, then repeat the affair many times. Therefore, some say, that tadabbur originates from the understanding of looking at the final parts of affairs and their consequences. In other words, looking at something behind something and understanding the consequences that will result.

The terminological definition, according to IbnulQoyyim: sharpens the eyes of the heart to the meanings of the Qur'an and concentrates the mind to contemplate and study them. Think deeply and thoroughly until the contents of the deepest meanings and the farthest goals. ${ }^{11}$ As the proof

\footnotetext{
${ }^{9}$ Mujam Al Wasith (1:174); Qamus Al-Munir, p. 265

10 Ahmad Muaffaq N, Fonologi Bahasa Arab (Cet. 2012; Makassar: Alauddin University Press, 2008), p. 3.

${ }^{11}$ Bakhtiar Nasir, al-Qur'an Tadabbur \& Praktiknya (Cet.I; Jakarta: AQL Pustaka, 2016), p. 10-11
} 
The Role of School Principal Leadership Quranic...

of tadabbur in the Qur'an. The Word of Allah Most High in QS Shod / 38: 29.

\section{Research Method}

This research is qualitative. According to Lexi J. Moleong, qualitative research is research that intends to understand the phenomenon of what is experienced by research subjects. for example behavior, perception, motivation, action, and others holistically and using description in the form of words and language, in a particular natural context, and by utilizing various natural methods. ${ }^{12}$ This research has illustrated the application of bothinternal and external conditions.

\section{Results and Discussion}

\section{A. Implementation of the Qur'anic Generation Development Program}

Studying the Koranrequires the right method to get good results. Teachers must beawarethatstudentswho come to schoolneedknowledge, especially in learning the Koran. Realizingvariousproblems in tahsin, tahfidz, and tadabbur alQur'an as students' knowledge and life principles. Teachers must alsobeawarethat the schoolitselfis a source of learningindirectly to the learning of the Koranstudents in schools.

${ }^{12}$ Lexi J. Moleong, Metodologi Penelitian Kualitatif (Cet. XXVII; Bandung: RemajaRosdakarya, 2010), p. 6. 
This applies to SD Athirah 1 Makassar, whereeachteacherisgiven class hours to teach and applylearningmethods in accordance with the material and conditions that support it. So itrequires good steps, among other things: ${ }^{13}$

1. Planning the Implementation of the Qur'anic Generation Development Program (Tahsin, Tahfidz and Tadabbur al-Qur'an)

Planning learning tahsidtahfidz and tadabbur alQuran as follows: ${ }^{14}$

a. System Standards Used in Learning Tahsin, Tabfidz and Tadabbur al-Qur'an

Tabsin in terms of the use of the Tabsin al-Qur'an learning system, SD Athirah has collaborated with quality Qur'an learning institutions that have been recognized by various institutions nationally, the Ummi Foundation Surabaya since 2013 and has received recognition by the trustees Athirah Islamic elementary school students with the results of a questionnaire the reason to send their children to Athirah, prioritizing the reason because of its good Qur'an learning. Tahfidz and tadabbur al-Qur'an, the Athirah school also uses a nationally known method, the Kaisa Method, which has conducted an MOU since 2017, even the founder of the Kaisa method is the one who directly teaches and his team at Athirah school. The Kaisa method is much in demand

${ }^{13}$ Interview with Khasan, 47 years old.

${ }^{14}$ Interview with Nuralam, 34 years old. 
The Role of School Principal Leadership Quranic...

by the community because of its unique method, by demonstrating the meaning of each reading of the Koran with movements that are in harmony with its meaning, so that students of Athirah elementary school in addition to memorizing the Koran correctly at the same time they understand the meaning or meaning from memorized verses that are visualized by movements that are in harmony with their meanings.

b. The Book Standards of Tabsin, Tabfidz and Tadabbur alQur'an

The book standards used in the Athirah Islamic Elementary School tahsin program using the UMMI Method book include: $:^{15}$

1) Books Volume 1 through 6 of the Ummi Method plus Ghorib and Tajwid.

2) The Qur'an used is RosmulUthmani and is highly recommended for the standard of the Qur'an Ummi.

3) Books supporting tahsin namely Waqoflbtida 'and Ummi standard achievements books and all of them are published by the Ummi Foundation Surabaya.

Tahfidz Islamic Athirah Elementary School uses the book "Easy Learning to Memorize al-Qur'an Ummi Method" if the memorization is still Juz 30, 29.28, 1 and 2. Besides that Athirah also uses the Qur'an directly 30 JuzRosmUtsmani for tahfidz. Tadabbur al-Qur'an is simple for Athirah Islamic Elementary School using AQL touchable Alquran and

${ }^{15}$ Interview with Khasan, 47 years old 
Tadabbur's book "Al-Qur'an Tadabbur\& Practical Guide to Interacting with the Qur'an".

c. Target Standards for Tabsin, Tabfidz and Tadabbur alQur'an

The target set at each level of education must be known in advance the level of tahsin and tahfidz which became the general standard as a reference for the determination of the target of Athirah 1 Makassar Islamic Elementary School.

\section{Implementation of Learning Tahsin, Tahfidz and Tadabbur al-Qur'an}

The learning process of tahsin, tahfidz and tadabbur has several standards, namely: ${ }^{16}$

a. Time

SD: 5 times per week with a minimum duration of 60 minutes for each meeting

b. Teacher Ratio ${ }^{17}$

The ratio of the ratio between teacher and student adjusts the condition of students faced by the teacher in the group. 1: 10 (one teacher faces ten students), which is highly recommended as an ideal class, cannot have more students if the ability of students varies.

c. Tahsin learning model $^{18}$

${ }^{16}$ Sekolah Islam Athirah, "Kurikulum Tabsin, Tabfidz, Tadabbur alQur'an" ( 10 Januari 2020)

${ }^{17}$ Interview with Nuralam, 34 years old.

${ }^{18}$ Interview with Nuralam, 34 years old. 
1) Individual Private

2) Individual Classics

3) Classical Reading Listen

4) Classical Read Pure Listen

d. Step of learnings ${ }^{19}$

1) Opening

2) Apperception

3) Planting concepts

4) Understanding of concepts

5) Exercise / skills

6) Evaluation

7) Closing

e. Time Description ${ }^{20}$

\begin{tabular}{|c|c|c|c|}
\hline Time & \multicolumn{2}{|c|}{ The activities } & Description \\
\hline \multirow{3}{*}{$\begin{array}{l}5 \\
\text { minutes }\end{array}$} & Preparation & $\begin{array}{l}\text { Salam } \\
\text { (greeting) }\end{array}$ & $\begin{array}{l}\text { Al-fatihah } \\
\text { Surah }\end{array}$ \\
\hline & $\begin{array}{l}\text { Opening } \\
\text { prayer }\end{array}$ & Ask & $\begin{array}{l}\text { Opening } \\
\text { prayer }\end{array}$ \\
\hline & & $\begin{array}{l}\text { Opening } \\
\text { prayer }\end{array}$ & \\
\hline \multirow{5}{*}{$\begin{array}{l}10 \\
\text { minutes }\end{array}$} & \multirow{5}{*}{ Memorization } & Apperception & \multirow{5}{*}{ On target } \\
\hline & & $\begin{array}{l}\text { Building } \\
\text { concept }\end{array}$ & \\
\hline & & Understanding & \\
\hline & & The skills & \\
\hline & & Evaluation & \\
\hline
\end{tabular}

${ }^{19}$ Interview with Nuralam, 34 years old.

${ }^{20}$ Interview with Nuralam, 34 years old. 


\begin{tabular}{|l|l|l|l|}
\hline $\begin{array}{l}10 \\
\text { minutes }\end{array}$ & Classical & Apersepsi & $\begin{array}{l}\text { Props } \\
\text { /books }\end{array}$ \\
\hline \multirow{3}{*}{$\begin{array}{l}30 \\
\text { minutes }\end{array}$} & \multirow{3}{*}{ Baca simak } & $\begin{array}{l}\text { Understanding } \\
\text { concept }\end{array}$ & \\
\cline { 3 - 3 } & & Understanding & $\begin{array}{l}\text { Setor } \\
\text { bacaan }\end{array}$ \\
\cline { 3 - 3 } & & The skills & \\
\cline { 3 - 4 } & & Evaluation & \\
\hline \multirow{3}{*}{\begin{tabular}{l} 
minutes \\
\cline { 3 - 3 }
\end{tabular}} & Review & $\begin{array}{l}\text { Dril materi } \\
\text { baru }\end{array}$ & Closing \\
\cline { 3 - 4 } & Closing pray \\
\cline { 3 - 4 } & & $\begin{array}{l}\text { Reviewing } \\
\text { memorization }\end{array}$ & Al-Qur'an \\
\hline
\end{tabular}

\section{B. Evaluation of the Implementation of Learning Qur'anic Generation Development Program (Tahsin, Tahfidz and Tadabbur al-Qur'an).}

Evaluating the implementation of learning tahsin, tahfidz and tadabbur al-qur'an divided into three namely: ${ }^{21}$ a. Daily evaluation

Every teacher must understand how to assess and determine page movement when students read their reading, the conditions are as follows:

\begin{tabular}{|c|c|l|}
\hline Value & Error & \multicolumn{1}{c|}{ Description } \\
\hline A $(90-100)$ & 0 One page error & $\begin{array}{l}\text { Going up to the next page has } \\
\text { the potential to be accelerated }\end{array}$ \\
\hline A- $(86-89)$ & 1 One page error & Go up to the next page \\
\hline
\end{tabular}

${ }^{21}$ Interview with Nuralam, 34 years old. 
The Role of School Principal Leadership Quranic...

\begin{tabular}{|l|l|l|}
\hline $\mathrm{B}(80-85)$ & 2 One page error & Go up to the next page \\
\hline $\mathrm{B}-(76-79)$ & 3 One page error & Repeating the page \\
\hline $\mathrm{C}(70-75)$ & 4 One page error & Repeats the page \\
\hline $\mathrm{D}(<70)$ & $\begin{array}{l}>4 \text { One page } \\
\text { error }\end{array}$ & $\begin{array}{l}\text { The page is given extra and } \\
\text { special attention }\end{array}$ \\
\hline
\end{tabular}

The above error requirement is to read independently without being guided by anyone, if you cannot fix it yourself then students cannot go up the page.

b. Evaluation of the increase in levels or volumes of Tahsin, Tahfidz and Tadabbur al-Qur'an

When a student has finished learning in one volume from pages 1 to 40, then the student has the right to be tested or tested to continue up to the next volume, provided the level increases: $:^{22}$

1) The examiner is the coordinator of the Qur'an teacher in the student school unit

2) Each school unit has only 1 examiner coordinator

3) Test material is taken from pages 1 to 40 one line per page

4) Value of 100 if 0 error, Go up next volume

5) Value of 95 if 1 error, move up the next volume

6) Value of 90 if 2 errors, go up next volume

7) Value of 85 if 3 errors, go up next volume

8) Value of 80 if 4 errors, move up the next volume

${ }^{22}$ Interview with Nuralam, 34 years old. 
9) Value 75 if 5 errors and can not go up the volume must repeat

10) $\mathrm{Kkm}$ value of 80 , so below 80 can not be up to volume.

c. Evaluation of the Results of Graduates or Final Examinations of Tahsin, Tahfidz and Tadabbur al-Qur'an When the whole series of learning has been passed, page after page, volume after volume so that the finish is ghorib and tajwid then the next is the final exam called Munaqosyah with the following conditions: ${ }^{23}$

1) Munaqosyah participants have received a recommendation from the coordinator.

2) Examiners were brought in from the Ummi Foundation.

3) Assessment is taken from a minimum of 5 aspects (Tartil, Fashohah, Tahfidz, Ghorib, Tajwid).

4) Graduation KKM score of 80.

5) Decision and award of certificates by the Ummi Foundation

C. Supporting Factors and Obstacles to the Implementation of the Qur'anic Generation Development Program (tahsin, tahfidz and tadabbur)

1. Factors supporting the implementation of the Qur'anic Generation Development Program (Tahsin, Tabfidz and Tadabbur al-Qur'an)

${ }^{23}$ Interview with Nuralam, 34 years old. 
The Role of School Principal Leadership Quranic...

Supporting factors in learning the Koran are in 3 main strengths, namely: ${ }^{24}$

a. Quality methods (al-Qur'an study books) consist of volumes 1-6, ghorib al-Qur'an, and basic recitation including teaching aids and learning methodology.

b.Al-Qur'an teacher, religion, and quality homeroom teacher, Teacher is one of the spearheads of the success or failure of an al-Qur'an learning program at school.

c. The quality-based system, this quality-based system is known as 10 pillars to achieve good quality. Between one pillar and another is a series that cannot be separated in its implementation. Among the following: ${ }^{25}$

1) Goodwill Management

2) Teacher Certification

3) Clear and Measured Targets

4) Consistent Mastery Learning

5) Adequate Time

6) Intensive Quality Control

7) Proportional Teacher and Student Ratio

8) Progress Report for Every Student

2. Factors inhibiting the implementation of the Qur'anic Generation Development Program (Tahsin, Tabfidz and Tadabbur al-Qur'an).

${ }^{24}$ Interview with Khasan, 47 years old

${ }^{25}$ Interview with Khasan, 47 years old. 
Difficulties experienced by students in learning tahsin, tahfidz, and tadabbur al-Qur'an will be apparent. The main factors affecting the difficulties experienced by students are derived from the students themselves, including ${ }^{26}$

a. Internal Factor

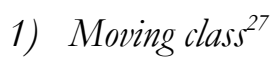

2) Homeroom class is not evenly distributed in terms of mastery of the Koran, because their educational backgrounds vary.

3) The teaching team of the Koran is uneven in class management, due to varied educational backgrounds, even some of them are not bachelor of education. But both in terms of tahsin, tahfidz and tadabbur al-Qur'an

4) Uneven implementation of matriculation for students with low ability, and is only implemented for students in grades 5 and 6 .

5) Student motivation is very varied towards learning the Koran.

6) Some students have difficulty in learning the Koran, among others:

7) Low memory.

b. Eksternal Factor ${ }^{28}$

1) Family factors.

2) The atmosphere of the house.

\footnotetext{
${ }^{26}$ Interview with Khasan, 47 years old.

${ }^{27}$ Interview with Khasan, 47 years old.

${ }^{28}$ Interview with Khasan, 47 years old
} 
The Role of School Principal Leadership Quranic...

3) The economic situation.

4) Social environment.

The factors in this discussion, we can see and analyze well, so that students can be overcome properly and given away to overcome them.

\section{Principal's Strategy in Guiding the Implementation of the Qur'anic Generation Development Program}

School principals are at the forefront in carrying out their leadership and their success can be measured. The final product of school principal leadership is school performance that changes both teachers and students. The change of teachers and students from those who do not know to know, from those who are inexperienced to experienced, from those who cannot become able to, from those who have no achievements to those who do.

The school principal has a strong role in shaping the quality of human beings he leads to becoming the next generation of a reliable nation. The leadership role of the Athirah 1 Makassar Islamic Primary School, in general, is as follows: ${ }^{29}$

1. Principal as an Educator

The role of the Athirah 1 Makassar Islamic Elementary School principal, in carrying out his function as an educator, among others: ${ }^{30}$

a. Have the right strategy to improve the professionalism of the teaching staff in their schools

${ }^{29}$ Interview with Khasan, 47 years old

${ }^{30}$ Interview with Khasan, 47 years old 
b. Placing teaching staff in the Koran in accordance with their competencies. Starting from volume 1 to volume 6 added to the Koran, ghorib, and basic recitation.

c. Advise school residents, students, and teachers. Especially those who come late to school and who neglect their duties inside and outside the classroom.

d. Implement an interesting learning model to achieve the target

e. Hold an acceleration program (acceleration) for students who have abilities above the average.

In connection with the development of the competence of al-Qur'an teachers, it can be proven that the Principal assigns al-Qur'an teachers to attend, workshops, seminars, training in learning the Koran, and conduct supervision, evaluation of learning activities that have been carried out.

2. Principal as a Manager

As a principal's manager has the right strategy to empower education staff with cooperation, provide opportunities for educators to improve their profession, and encourage the involvement of all teaching staff in various activities that support school programs.

The principal of Athirah 1 Makassar Elementary School as a manager has carried out its functions, including ${ }^{31}$ a. Making work programs learning tahsin, tahfidz, and tadabbur al-Qur'an.

${ }^{31}$ Interview with Khasan, 47 years old 
The Role of School Principal Leadership Quranic...

b. Making a quality guarantee of memorizing 3 juz and 6 volumes of basic lessons to ghorib and basic recitation for elementary school level. This can be seen learning tabsin, tabfidz and tadabbur al-Qur'an

c. Arranging the learning program of al-Qur'an which in its preparation involves the foundation, the religious department, the principal, the deputy head of the religious field and the teacher of the Koran.

d. Arranging staffing organizations in schools this is evident from the existence of the school organizational structure, the organization of the Qur'an teacher team.

e. Arranging the committee for each activity such as evaluating the learning of tabsin, tabfidz, and tadabbur Qur'an both for Mid Semester, final semester assessment, and also the sermon of the Qur'an.

This shows that the principal as a manager performs his functions optimally in the environment of SD Athirah 1 Makassar Elementary School.

3. Principal as an Administrator

Regarding the role of the Athirah 1 Makassar Islamic Elementary School as the administrator, the role of the principal is closely related to the recording, compilation, and documenting activities of all school programs. Specifically, the school principal has carried out his function as an administrator, including ${ }^{32}$

a. Manage the administration of school curricula both at the national level or the curriculum of autonomous institutions.

${ }^{32}$ Interview with Khasan, 47 years old 
b. Manage student administration by arranging schedules, when to study, rest time, and playtime or socializing with the surrounding environment.

c. Managing administrative personnel such as Administration, Teachers, graduate students, and others related to planning, development, assessment, promotion, and welfare.

d. Manage staffing administration that supports school activities effectively and efficiently for the achievement of educational goals that have been set.

These activities must be carried out effectively and efficiently to support school productivity. Principals who carry out their functions as administrators are closely related to various administrative management activities that are recording, compiling, and documenting all school programs. As well as regularly checking the administration of the teacher.

4. Principal as a Supervisor

The principal of the Athirah 1 Makassar Islamic Elementary School has performed its function as a supervisor who supervises the work carried out by teaching staff, especially the Qur'an teacher. As for what the principal is doing as a supervisor as follows: ${ }^{33}$

a. The principal has conducted various supervision and control to improve the performance of the teaching staff so that the educational activities in the school are directed to the stated goals.

\footnotetext{
${ }^{33}$ Interview with Khasan, 47 years old
} 
The Role of School Principal Leadership Quranic...

b. Have taken preventive measures to prevent educators from making deviations and to be more careful in carrying out their work.

c. The principal as a supervisor has realized the ability to compile, and implement an educational supervision program, as well as utilizing the results.

d. Periodically the principal needs to carry out supervision activities, which can be done through class visit activities to observe the learning process directly, especially in the selection and use of methods, media used, and student involvement in the learning process.

e. The Principal has provided guidance, assistance, supervision, and assessment on issues related to the implementation of the Qur'anic Generation Development Program to be able to create a teaching and learning situation.

From the results of this supervision, it can be seen the weaknesses as well as the teacher's excellence in implementing learning, the level of mastery of the competency of the teacher concerned, then sought solutions, coaching, and certain follow-up so that the teacher can correct the existing shortcomings while maintaining its superiority in implementing learning.

5. Principal as a leader

Principal's leadership can foster creativity while at the same time can encourage teacher competency improvement. To improve teacher competency, a school principal can apply leadership styles appropriately and flexibly, adapted to the existing conditions and needs. The work ethic of the teacher 
is higher when led by the school principal with a leadership style oriented to school conditions.

The principal of the Athirah 1 Makassar Islamic Elementary School as a leader has made its functions available, among others: ${ }^{34}$

a. Provide guidance and supervision, improve the ability of teaching staff, and delegate tasks.

b. As the executor may not impose his own will on the group. As well as trying to meet the desires and needs of the group, also programs that have been set together.

c. As a planner must make and arrange plans, so that everything that will be done is not just arbitrary, but all actions are calculated and aimed.

d. As an expert who has the expertise, especially related to the leadership positions he holds.

e. Oversee the relationships between group members so that there are no disputes and try to build harmonious relationships with fellow teachers.

This is proof that leaders have tried their best to carry out their functions.

6. Principal as an innovator

Principals to perform their roles and functions as innovators are "principals must have the right strategy to establish harmonious relationships with the environment, seek new ideas, integrate every activity, set an example for all teaching staff in schools, and develop learning models innovatively.

\footnotetext{
${ }^{34}$ Interview with Khasan, 47 years old
} 
The Role of School Principal Leadership Quranic...

The head of the Athirah 1 Makassar school as an innovator has sought, found, and implemented various innovations in schools towards the implementation of learning the Koran, among others: ${ }^{35}$

a. For example, moving class (changing the learning strategy of al-Qur'an from class patterns into groups according to their respective volumes.

b. Providing teaching aids and other tools to help facilitate learning.

c. Making small classes for learning the Koran can be maintained by the teacher (facilitator), whose job is to provide convenience to students in learning the Koran.

d. Create a small-scale classroom in a particular place for learning the Koran.

e. Performing murajaah together before and after praying in congregation to pray dzhur and asr prayer.

The school principal as an innovator has reflected on how to do his work constructively, creatively, negatively, rationally, and objectively, exemplary, disciplined, and flexible. In this case the Principal of the Islamic elementary school Athirah 1 Makassar in carrying out its function as an excellent innovator.

7. Principal as a Motivator

The principal of the Athirah 1 Makassar Islamic Elementary School has provided motivation to educators and students, as follows: ${ }^{36}$

${ }^{35}$ Interview with Khasan, 47 years old

${ }^{36}$ Interview with Khasan, 47 years old 
a. Through the approach of spiritual religion by holding religious lectures conducted by containing directions to increase aqeedah and morals for educators and students.

b. Give examples of achievement to encourage teachers and students to excel in the smallest form, for example completing tasks and responsibilities properly

c. Give recognition of the students what is achieved in the form of praise or congratulations whether formal or informal situation.

d. Give time to increase the knowledge, experience, and abilities possessed by educators and students.

e. Giving responsibility as a form of trust to educators and students of the task or authority is given, this trust can make educators and students motivated to improve their abilities.

As a school principal, the Principal of the Athirah 1 Makassar Islamic Elementary School motivates teachers to always improve their knowledge and competence. Based on interviews with all components of education in Athirah 1 Makassar Islamic Elementary School including its stakeholders, assessing that the school principal can carry out his duties and functions with very good.

\section{Conclusion}

Based on the results of field research on the role of school principals' leadership towards the implementation of the Qur'anic Generation Development Program (Tahsin, 
The Role of School Principal Leadership Quranic...

Tahfidz, and Tadabbur) at the Athirah 1 Islamic Elementary School in Makassar.

The implementation of the Qur'anic Generation Development Program (Tahsin, Tahfidz, and Tadabbur) in learning the Koran is adjusted to the reading level of the students' reading. The ability of students in the implementation of tahsin, tahfidz and tadabbur al-Qur'an viewed from the test results, it can be concluded that the average ability for tahsin, tahfidz, and tadabbur al-Qur'an belongs to the sufficient category

The role of the principal's leadership in the implementation of the Qur'anic Generation Development Program (Tabsin, Tabfid\%, and Tadabbur) in the Athirah I Elementary School, Makassar. Going well and optimally and can be described as follows: a) as an educator (educator), b) as a manager, c) as an administrator, d) as a supervisor, e) as a leader, f) as an innovator, and g) as a motivator.

\section{REFERENCES}

A.W. Munawwir, Kamus Al-Munawwir Arab-Indonesia. Cet.XIV; Surabaya: PustakaProgressif 1997.

Anwar,MochIdochi.Administrasi Pendidikan dan Manajemen Biaya Pendidikan. Bandung: Alfabeta, 2004.

Arikunto, Suharsimi. Organisai dan Administrasi Pendidikan Teknologi dan Kejuruan. Jakarta: CV. Rajawali, 1990. Kementrian Agama RI. Al-Qur'an dan Terjemahan.Cet. 16, Jakarta: Darussunnah, 2011. 
M. Fu,ad Abdul Baqi, Al-Lu'luwalMarjan. Cet.XIII; Surabaya: PT Bina Ilmu 2017.

M. QuraishShihab, Tafsir al-Mishbah: Pesan, KesandanKeserasian al-Qur'an, volume I, cet. Ke-2, Jakarta: LenteraHati, 2004.

Masniati "KepemimpinanDalam Islam”. Jurnal Al-Qadau, Vol 2 No 1 (2015): h. 58-64.

Moleong, Lexi J.MetodologiPenelitianKualitatif. Cet. XXVII; Bandung: RemajaRosdakarya, 2010.

Muaffaq, Ahmad. Fonologi bahasa Arab. Cet. 2012; Makassar: Alauddin University Press, 2008.

Mulyasa.Standar Kompetensi dan Sertifikasi Guru.Bandung : Remaja Rosdakarya, 2007.

Nasir, Bakhtiar. Al-Qur'an Tadabbur \& Praktiknya. Cet.I; Jakarta: AQL Pustaka, 2016.

Wahjosumidjo. Kepemimpinan Kepala Sekolab Tinjauan Teoritik dan Permasalahannya. Jakarta: Raja Grafindo Persada, 2005.

Interview

Khasan, School Principal of Athirah Islamic Primary School NurAlam, Teacher Cordinator in Quranic Generation Development Program 